\title{
EVALUATING THE QUALITY OF LIFE OF ELDERLY PEOPLE WHO ATTEND CLASSES AT THE UNIVERSITY OF THE THIRD AGE
}

\author{
OCENA JAKOŚCI ŻYCIA OSÓB UCZESTNICZĄCYCH \\ W ZAJĘCIACH UNIWERSYTETÓW TRZECIEGO WIEKU
}

\author{
${ }^{1}$ Department and Clinic of Geriatrics of the Nicolaus Copernicus University in Toruń \\ Collegium Medicum in Bydgoszcz \\ ${ }^{2}$ Department of the Nicolaus Copernicus University in Torun \\ Collegium Medicum in Bydgoszcz
}

S u m m a ry

Introduction. The period of older age - the third age - is commonly perceived as the period of inactivity and withdrawal from social life, and with growing intellectual and physical limitations. As a result, older people are often isolated from active life. Universities of the Third Age are organisations that offer lifelong education to elderly people. The main goal of the Universities is to activate people who are in their third age socially, intellectually and physically, and at the same time to engage these people in the community life.

The a i m of the study was to evaluate the quality of life of elderly people who attend classes at the University of the Third Age at the beginning of their education and after one year of attending the classes. For this purpose the WHOQOL-BREF questionnaire was used.

Material and methods. The study comprised 127 people aged $60-80$ who started their classes at the University of the Third Age. After one year of their attendance in the classes 108 students participated in the second stage of the study.

Results. The average number of points obtained at the end of the classes at the University of the Third Age in all the four spheres was statistically higher compared to the average number of points obtained at the beginning of the academic year. The largest change was observed in the physical and social relationships spheres. In the physical sphere the average number of points at the beginning of classes was $14.93 \pm 2.10$, and after one year $15.51 \pm 1.91$ $(\mathrm{p}=0.0000)$. In the sphere of relationships the average number of points at the beginning of the academic year was $13.99 \pm 2.29$, while at the end of the academic year $14.90 \pm$ $1.95(\mathrm{p}=0.0000)$.

Conclusions. Supporting elderly people in having an active lifestyle is necessary and it may have a beneficial impact on their perception of the quality of life.

\section{Streszczenie}

W s tęp . Okres starości często kojarzony jest z biernością i wycofaniem się z życia społecznego, a także ograniczeniem możliwości intelektualnych i fizycznych. Takie postrzeganie osób starszych wyklucza je z aktywnego funkcjonowania. Uniwersytety Trzeciego Wieku są placówkami oświatowymi, przeznaczonymi dla osób w podeszłym wieku. Głównym celem tych instytucji jest aktywizacja społeczna, intelektualna i fizyczna osób starszych oraz pogłębianie ich wiedzy, przy jednoczesnym angażowaniu osób w wieku podeszłym w działalność na rzecz środowiska lokalnego.

Celem badań była ocena jakości życia osób uczestniczących w zajęciach UTW na początku edukacji i po roku uczestnictwa w zajęciach przy użyciu kwestionariusza WHOQOL-BREF.

Materiał i metody. Badaniami objęto 127 osób w wieku od 60 do 80 lat rozpoczynających zajęcia na UTW. 
Do drugiego etapu badań, które przeprowadzono po rocznym udziale w zajęciach przystąpiło 108 osób.

Wyniki. Średnia liczba punktów uzyskanych na końcu zajęć na UTW we wszystkich czterech dziedzinach była istotnie statystycznie wyższa od średniej liczby punktów uzyskanych na początku roku akademickiego. W dziedzinie fizycznej i relacji społecznych obserwowano największą zmianę. W dziedzinie fizycznej średnia liczba punktów na

Key words: quality of life, University of the Third Age, old age

Slowa kluczowe: jakość życia, Uniwersytet Trzeciego Wieku, wiek podeszły

\section{INTRODUCTION}

Recent studies show that the increase in the population of elderly people influences the society in many aspects. The growing population of elderly people, who often suffer from chronic diseases, is a burden to the system of care, and especially to the health system. Therefore, a society's duty is to support older people to remain healthy and independent for as long as possible. This is particularly important as with ageing functioning in basic and complex everyday activities usually worsens to a great extent $[1,2]$. The longer the elderly stay independent, the better their quality of life, and the better their social relations. [3]. Activity plays a vital role in adapting to changes and remaining healthy at the older age. Activity and its other forms (e.g. intellectual activity, physical activity, social activity) can save many problems of the older age. Active people experience less problems and obstacles related to age [4]. Encouraging elderly people to stay active, in any form, can improve their quality of life. Universities of the Third Age activate elderly people in intellectual, physical and social spheres. Elderly people not only acquire education and knowledge in various subjects, but they are also able to become an active part of the society. Elderly people who attend classes integrate with their peers and by this build social relations which have ceased due to the loss of their social roles. Universities of the Third Age also contribute to the better understanding of the problem of ageing and old age, and by this to the increase in the number of organisations which support older people in improving their quality of life. The aim of this study was to compare the quality of life of older people who start their education with the quality of life after one year of education at the University of the Third Age. początku zajęć wynosiła $14,93 \pm 2,10$, a po roku $15,51 \pm 1,91$ $(\mathrm{p}=0,0000) . \mathrm{W}$ dziedzinie relacji społecznych średnia liczba punktów na początku roku akademickiego wynosiła 13,99 \pm 2,29 , a $14,90 \pm 1,95$ na końcu roku akademickiego $(\mathrm{p}=0,0000)$.

W ni oski. Aktywizacja osób starszych jest celowa i może korzystnie wpływać na postrzeganie jakości życia.

\section{MATERIALS AND METHODS}

The study comprised 127 people who started their education the University of the Third Age. The people were selected among those who attended Universities of the Third Age in the Kujawsko -Pomorskie Province. Among those who qualified there were 106 (83.5\%) women aged 60-79 and 21 (16.5\%) men aged 61-80. At the end of the academic year 108 people participated in the study. Among the students who participated in the study at the beginning of their education, a number of the students discontinued their education, and some did not want to participate in the second stage of the study, while some did not fill the questionnaire, although they participated in the second stage of the study. The study was carried out with the use of the WHOQOL-BREF questionnaire which is an abbreviated version of the life quality evaluation tool. The questionnaire was adapted to the Polish culture by Laura Wałowicka and Krystyna Jaracz [26]. The questionnaire shows the quality of life profile in four spheres: physical health, psychological, social relationships, environment and subjective general assessment of the quality of life and health. The WHOQOL-BREF questionnaire consists of 26 questions [26]. The results were analysed statistically. Statistical significance limit was adopted on the level $\mathrm{p}=0.05$.

\section{RESULTS}

With the use of WHOQOL- BREF questionnaire four spheres were evaluated: physical, psychological, social relationships and environment. In each sphere the result remained between 4 and 20 points. Higher number of points means better quality of life. The distribution of the number people in relation to the number of points obtained in the WHOQOL-BREF questionnaire in each sphere in the group under study before the beginning of the academic year $(n=127)$ is 
shown in Figure 1. The study showed no relation between the age and the number of points in the WHOQOL-BREF questionnaire in each sphere: physical, psychological, social relationships and environment. It has also been observed that age had no influence on the quality of life of the people under study. The WHOQOL-BREF questionnaire was used again at the end of the academic year. The quality of life of 108 people who participated in the study both at the beginning and at the end of the academic year was compared. The average number of points obtained at the end of the classes at the University of the Third Age in all four spheres statistically increased significantly compared to the average number of points obtained at the beginning of the academic year (table 1). The greatest change was observed in the physical and social relationships spheres. In the physical sphere the average number of points at the beginning of classes was $14.93 \pm 2.10$, and after one year $15.51 \pm 1.91(\mathrm{p}=0.0000)$. In the sphere of social relationships the average number of points was $13.99 \pm 2.29$ at the beginning, and $14.90 \pm$ 1.95 at the end of the academic year $(p=0.0000)$. The results obtained from the WHOQOL-BREF questionnaire in physical sphere after one year of attending the classes did not change in 24 people, in 26 decreased and in 58 increased. In 22 no changes were observed, in 27 a decrease was observed and in 59 the number of points increased in the psychological sphere. In the social relationships the results of the questionnaire remained unchanged in 45 people, in 8 decreased and in 55 increased. In the sphere of the environment in 15 the results did not change, in 31 decreased and in 62 the number of points obtained in the WHOQOL-BREF questionnaire increased. Tables 2 and 3 show the distribution of points obtained in the general question about the quality of life and condition of health before and after the classes at the University of the Third Age. The subjective opinion on the quality of life did not significantly change in statistics after one year $(\mathrm{p}=0.1590) .7$ people $(6.5 \%)$ assessed the quality of life on the highest level, whereas 6 people were the same at the beginning and at the end. In 89 people $(82.4 \%)$ the assessment did not change, in 13 increased (12.0\%), and in 66 decreased (5.6\%). Subjective assessment on the conditions of health significantly changed in the statistics after one academic year $(p=0.0071)$. In 70 people $(64.8 \%)$ the assessment did not change, in 28 it increased (25.9\%), and in 10 it decreased (9.3\%).

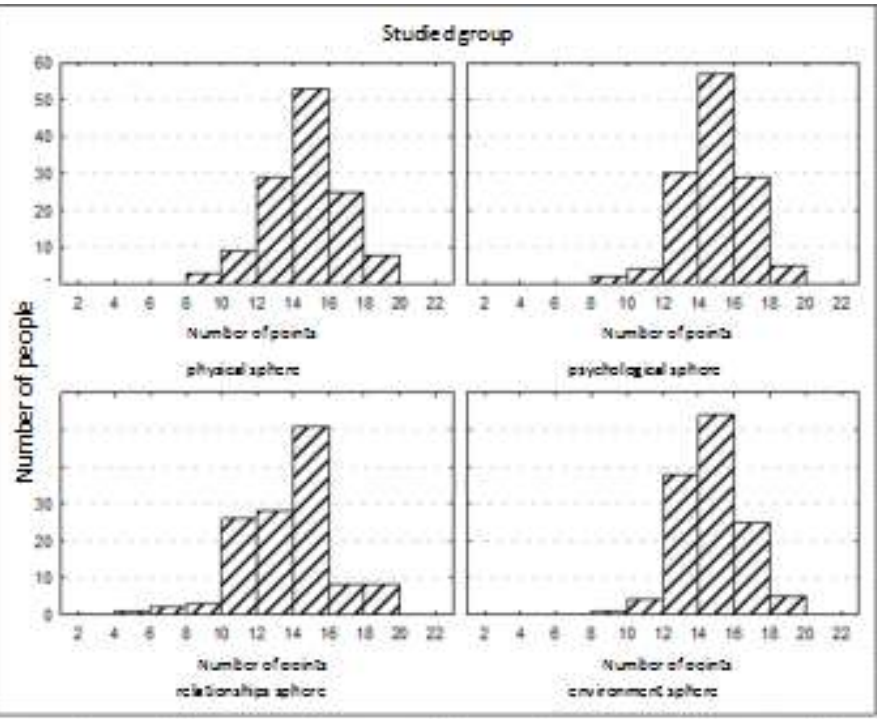

Fig. 1. Distribution of the number of people in relation to the number of points obtained in the WHOQOL-BREF questionnaire at the beginning of the academic year

Ryc. 1. Rozkład liczby osób względem liczby punktów w kwestionariuszu WHOQOL-BREF na początku roku

Table 1. The average number of points in each sphere obtained in the WHOQOL-BREF questionnaire at the beginning and after one year of the academic year

Tabela 1. Średnia liczba punktów $w$ poszczególnych dziedzinach uzyskana $w$ kwestionariuszu WHOQOL-BREF na poczatku i po uptywie roku akademickiego

\begin{tabular}{|l|c|c|c|c|c|c|c|}
\hline \multirow{3}{*}{ Sphere } & \multicolumn{3}{|c|}{ At the beginning } & \multicolumn{3}{c|}{ After one year } & \multirow{2}{*}{ P } \\
\cline { 2 - 7 } & $\begin{array}{c}\text { Average } \\
\pm \text { SD }\end{array}$ & Min. & Max. & $\begin{array}{c}\text { Average } \\
\pm \text { SD }\end{array}$ & Min. & Max. & \\
\hline Physical & $\begin{array}{c}14.93 \pm \\
2.10\end{array}$ & 9.14 & 20.00 & $\begin{array}{c}15.51 \pm \\
1.91\end{array}$ & 9.71 & 19.43 & $\mathrm{p}=0.0000$ \\
\hline Psychological & $\begin{array}{c}15.34 \pm \\
1.84\end{array}$ & 8.67 & 20.00 & $\begin{array}{c}15.81 \pm \\
1.74\end{array}$ & 12.00 & 19.33 & $\mathrm{p}=0.0005$ \\
\hline $\begin{array}{l}\text { Social } \\
\text { Relationships }\end{array}$ & $\begin{array}{c}13.99 \pm \\
2.29\end{array}$ & 8.00 & 20.00 & $\begin{array}{c}14.90 \pm \\
1.95\end{array}$ & 10.67 & 20.00 & $\mathrm{p}=0.0000$ \\
\hline Environment & $\begin{array}{c}15.06 \pm \\
1.61\end{array}$ & 11.50 & 19.00 & $\begin{array}{c}15.42 \pm \\
1.65\end{array}$ & 12.00 & 20.00 & $\mathrm{p}=0.0121$ \\
\hline
\end{tabular}

Table 2. Number of points obtained in the general question about the quality of life at the beginning and at the end of the academic year

Tabela 2. Liczba punktów uzyskanych $w$ pytaniu ogólnym dotyczacym jakości życia na początku $i$ po uptywie roku akademickiego

\begin{tabular}{|l|c|c|c|c|c|c|c|c|c|c|}
\hline \multirow{2}{*}{$\mathrm{N}=108$} & \multicolumn{10}{|c|}{ No of points } \\
\cline { 2 - 11 } & \multicolumn{2}{|c|}{} & \multicolumn{2}{|c|}{2} & \multicolumn{3}{|c|}{3} & \multicolumn{2}{|c|}{5} \\
\cline { 2 - 10 } & $\mathrm{N}$ & $\%$ & $\mathrm{~N}$ & $\%$ & $\mathrm{~N}$ & $\%$ & $\mathrm{~N}$ & $\%$ & $\mathrm{~N}$ & $\%$ \\
\hline $\begin{array}{l}\text { At the beginning of } \\
\text { classes }\end{array}$ & 0 & 0.0 & 0 & 0.0 & 26 & 24.1 & 75 & 69.4 & 7 & 6.5 \\
\hline After one year & 0 & 0.0 & 0 & 0.0 & 19 & 17.6 & 82 & 75.9 & 7 & 6.5 \\
\hline
\end{tabular}


Table 3. Number of points obtained in the general question about health at the beginning and at the end of the academic year

Tabela 3. Liczba punktów uzyskanych $w$ pytaniu ogólnym dotyczacym zdrowia na poczatku i po uptywie roku akademickiego

\begin{tabular}{|l|c|c|c|c|c|c|c|c|c|c|}
\hline \multirow{2}{*}{$\mathrm{N}=108$} & \multicolumn{10}{|c|}{ No of points } \\
\cline { 2 - 11 } & \multicolumn{2}{|c|}{1} & \multicolumn{2}{|c|}{2} & \multicolumn{3}{|c|}{} & \multicolumn{2}{|c|}{5} \\
\cline { 2 - 11 } & $\mathrm{N}$ & $\%$ & $\mathrm{~N}$ & $\%$ & $\mathrm{~N}$ & $\%$ & $\mathrm{~N}$ & $\%$ & $\mathrm{~N}$ & $\%$ \\
\hline $\begin{array}{l}\text { At the beginning of } \\
\text { classes }\end{array}$ & 1 & 0.9 & 15 & 13.9 & 33 & 30.5 & 57 & 52.8 & 2 & 1.9 \\
\hline After one year & 1 & 0.9 & 5 & 4.6 & 36 & 33.3 & 61 & 56.5 & 5 & 4.6 \\
\hline
\end{tabular}

\section{DISCUSSION}

In recent years an increased interest in the issue of ageing has been observed. Scientifically this problem is recognized as a complex phenomena studied in many disciplines. The process of ageing is examined not only in biology and medicine, but also in social sciences and even philosophy [6]. Research in this subject shows that all these disciplines of science have a great influence on encouraging elderly people to have an active lifestyle. Academic and various social organizations meet not only the elders' educational, but also social needs. However, Universities of the Third Age are usually located in big cities and are not accessible to all those who are interested in attending the classes [7]. So far no study has been carried out concerning changes in the quality of life of the students of Universities of the Third Age in the KujawskoPomorskie Province. Therefore, this problem underlies the motivation for this study herein. The main purpose of the study was to evaluate the impact of the attendance in the classes on the quality of life. In their response to the general question about the satisfaction from the quality of life $69.4 \%$ students assessed it as good, while $6.5 \%$ as very good. In this group $52.8 \%$ assessed their health as good, and as few as $1.9 \%$ as very good. The results may suggest that people who attend classes at the University of the Third Age perceive themselves as physically healthy and active. However, they feel less comfortable in the sphere of social relationships, which may have motivated them to make a decision to attend the classes at the University of the Third Age. These students probably expect that their attendance allows them to be present in social life and will result in more social contacts. The analysis of the results after one year of attendance at the University of the Third Age showed that the average number of points in all four spheres of life statistically increased significantly compared to the average number of points obtained at the beginning of the academic year (table 1). The largest change was observed in the sphere of physical condition and social relationships. In the physical condition the average number of points at the beginning of classes was 14.93 \pm 2.10 , and after one year $15.51 \pm 1.91$. Although the quality of life in the physical sphere had been declared as good already at the beginning of classes, after one year of classes at the University of the Third Age the assessment improved. At the same time, in the social relationships sphere, where at the beginning of classes the students declared the lowest quality of life, after one academic year it improved the most significantly $(p=0.0000)$. The analysis of the responses to general questions about the quality of life and condition of health at the end of classes showed no statistically significant improvement in the general quality of life after one academic year $(p=0.1590)$. However, the general assessment of health after one year of classes at the University of the Third Age improved significantly $(\mathrm{p}=0.0071)$. These results may suggest that the wellbeing in the spheres of physical activity and social relationships are related to the perception of the condition of health as generally good. Physical and intellectual activity is therefore necessary and may influence the perception of the quality of life. Castro et al. had similar observations with the use of WHOQOL-BREF questionnaire and SF-36 questionnaire for the evaluation of the quality of life in a group of 70 people who started to attend a University of the Third Age and who participated in the special programme for physical activity. After four months of the participation in the programmer statistical number of points in WHOQOL-BREF questionnaire significantly increased in the sphere of environment $(\mathrm{p}=0.0001)$ and psychology $(\mathrm{p}=0.003)$ as well as in the two questions about general satisfaction from the quality of life $(p=0.006)$ and condition of health $(p=0.05)$. They also observed that at the same time the average number of points increased in SF-36 questionnaire in the question about individual and general opinion about own perception of the condition of health $(\mathrm{p}=0.013)$ [8]. The analysis of this study, as well as the observation made by Castro et al. suggests that physical and intellectual activity may prevent low assessment of the quality of life, regardless the age and the ageing process. On the other hand, the age does not necessarily have to determine the worsening of the quality of life [8,9]. It should be emphasized that this study did not show any dependence between the age 
and the quality of life. Watt and Konnert in their research also did not observe any significant difference between the quality of life and the age of the people under study [10]. However, Ostrzyżek in the analysis of the relationship between the age and the assessment of the quality of life noticed a statistically significant negative correlation [11]. Mercier et al. observed a reverse correlation [12]. Rennó et al. in their study prove that the age does not determine the worsening of the quality of life [9]. Studies of the authors show that social isolation and lack of any activity have an impact on the perception of the quality of life, including the assessment of own health, and the risk of developing depression in the people in this age group. [13-17]. Good life style and life-long education of the students of Universities of the Third Age has a good influence on their well-being, which observation is supported by other studies [18, 19].

\section{CONCLUSIONS}

Improved quality of life in all spheres of life after one year of attendance in classes at the University of the Third Age allows to conclude that this type of activating elderly people is necessary and may have a positive impact on the perception of the quality of life, especially in the sphere of social relationships.

\section{REFERENCES}

1. Biercewicz M., Kędziora-Kornatowska K., Ślusarz R., Cegła B., Faleńczyk K.: Ocena wydolności czynnościowej osób $\mathrm{w}$ wieku podeszłym na tle uwarunkowań zdrowotnych i społecznych. Pielęg XXI w 2005; 1/2: 39-45.

2. Kędziora-Kornatowska K., Połocka-Molińska M., Kuczma-Napierała J., Wysoczyńska M., Kornatowski T.: Analiza wybranych czynników wpływających na psychofizyczną charakterystykę pacjentów w wieku podeszłym. Ann Acad Med Siles 2005; 59: 302-308.

3. Reichstadt J., Depp C.A., Palinkas L.A., Folsom D.P., Jeste D.V.: Building blocks of aging: a focus group study of older adults' perceived contributors to successful aging. Am J Geriatr Psychiatry 2007; 15: 194-201.

4. Gębska-Kuczerowska A.: Ocena zależności między aktywnością a stanem zdrowia ludzi w podeszłym wieku. PrzeglEpidemiol 2002; 56: 471-477.

5. Jaracz K., Wołowicka L.: Polska wersja WHOQOL-100 i WHOQOL BFER (red.): Jaracz K., Wołowicka L.: Jakość życia w naukach medycznych. Wydawnictwo Akademii Medycznej w Poznaniu, Poznań 2001: 235281.
6. Polak A., Porzych K., Kędziora-Kornatowska K., Motyl J., Porzych M., Słupski M., Lackowska D.: Poznawczy i praktyczny wymiar gerontologii - interdyscyplinarnej nauki o starzeniu się i starości. Gerontol Pol 2007; 15: 51-53.

7. Błachnio A.: Wolontariat $\mathrm{w}$ Uniwersytetach Trzeciego Wieku, Wyd. UKW, Bydgoszcz 2008:19-48.

8. Castro P.C., Tahara N., Rebelatto J.R., Driusso P., Aveiro M.C., Oishi J.: influence of The Open University For The Third Age (UATI) and the revitalization program (REVT) on quality of life in middle-aged and elderly adults. Rev bras fisioter 2007; 11: 461-467.

9. Rennó A.C.M., Granito R.N., Driusso P., Costa D., Oishi $\mathrm{J} .:$ Effects of an exercise program on respiratory function, posture and on quality of life in osteoporotic women: a pilot study. Physiotherapy 2005; 91: 113-118.

10. Watt A., Konnert C.: Quality of life in the nursing home: perspectives of younger and older residents. Can J Aging 2007; 26: 403-410.

11. Ostrzyżek A.: Ocena jakości życia osób w podeszłym wieku, rehabilitowanych w oddziale opieki długoterminowej. Probl Hig Epidemiol 2010; 91: 659666.

12. Mercier C., Péladeau N., Tempier N.: Age, gender and quality of life. Community Ment Health J 1998; 34: 487500 .

13. Adams K.B., Sanders S., Auth E.A.: Loneliness and depression in independent living retirement communities: risk and resilience factors. Aging \& Mental Health 2004; 8: 475-485.

14. Alexandre T.S., Cordeiro R.C., Ramos L.R.: Factors associated to quality of life in active elderly. Rev SaúdePública 2009; 43: 613-21.

15. Gabriel Z., Bowling A.: Quality of life from the perspectives of older people. Ageing \& Society 2004; 24 : 675-691.

16. Netuveli G., Blane D.: Quality of life in older ages. Br Med Bull 2008; 85: 113-126.

17. Paul C., Ayis S., Ebrahim S.: Psychological distress, loneliness and disability in old age Psychology. Health\&Medicine 2006; 11: 221-232.

18. Kędzia A., Szymanowska I., Huszla S., Karakiewicz B., Mroczek B.: Możliwość wpływu na własną starość w ocenie słuchaczy uniwersytetu Trzeciego Wieku. Ann UnivMariae Curie Sklodowska [Med] 2004; 59: 462465.

19. Zielińska-Więczkowska H., Kędziora-Kornatowska K.: Jakość starzenia się i starości w subiektywnej ocenie słuchaczy Uniwersytetu Trzeciego Wieku. Gerontol Pol 2009; 17: 137-142. 


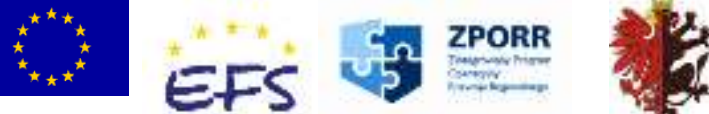

Projekt jest współfinansowany przez Unię Europejską

z Europejskiego Funduszu Społecznego oraz Budżetu Państwa w ramach Zintegrowanego Programu Operacyjnego

Rozwoju Regionalnego
Address for correspondence:

dr Anna Grzanka-Tykwińska

Department and Clinic of Geriatrics

of the Nicolaus Copernicus University in Torun

Collegium Medicum in Bydgoszcz

85-094 Bydgoszcz

M. Curie-Skłodowskiej 9 Street

$\mathrm{Tel} /$ fax (052)-585-49-00

e-mail: grzankaanna@wp.pl

Received: 14.10.2014

Accepted for publication: 17.11.2014 